\title{
Preparation and Characterization of Bacterial Cellulose Composites with Silver Nanoparticles
}

\author{
Ivan P. Shidlovskiy ${ }^{\mathrm{a}}$, \\ Anna A. Shumilova*a and Ekaterina I. Shishatskaya ${ }^{\text {a,b }}$ \\ ${ }^{a}$ Siberian Federal University \\ 79 Svobodny, Krasnoyarsk, 660041, Russia \\ ${ }^{b}$ Institute of Biophysics $S B$ RAS \\ Federal Research Center \\ "Krasnoyarsk Science Center SB RAS" \\ 50/50 Akademgorodok, Krasnoyarsk, 660036, Russia
}

Received 27.03.2017, received in revised form 21.05.2017, accepted 23.05.2017

\begin{abstract}
Bacterial cellulose (BC) is widely used in medicine as a dressing material due to its good biological properties - high biocompatibility, low adhesion and the ability to absorb wound exudate. The BC does not have antimicrobial activity itself, which limits the use of products in infected wounds, and also treatment of wounds in hospitals. A method for producing a two-component composite material based on bacterial cellulose (BC) synthesized in culture of Komagataeibacter xylinus B-12068 with silver nanoparticles [BC/AgNps], by hydrothermal synthesis of $\mathrm{AgNO}_{3}$ in the layer of $\mathrm{BC}$ at different temperatures and concentrations of $\mathrm{AgNO}_{3}$, is proposed. The antibacterial activity of BC/AgNps samples against Escherichia coli, Pseudomonas aeruginosa, Klebsiella pneumonia, and Staphylococcus aureus has been confirmed in vitro with the disc diffusion method. It is shown, that the antibacterial activity of samples is mostly expressed in cultures of P. aeruginosa and S. aureus.
\end{abstract}

Keywords: bacterial cellulose, wound dressings, silver nanoparticles, composites, antibacterial activity.

Citation: Shidlovskiy I.P., Shumilova A.A., Shishatskaya E.I. Preparation and characterization of bacterial cellulose composites with silver nanoparticles. J. Sib. Fed. Univ. Biol., 2017, 10(2), 255-264. DOI: 10.17516/1997-1389-0027.

(C) Siberian Federal University. All rights reserved

* Corresponding author E-mail address: shumilova.ann@mail.ru 


\title{
Способ получения и характеристики композитов бактериальной целлюлозы и наночастиц серебра
}

\author{
И.П. Шидловский ${ }^{\mathrm{a}}$, А.А. Шумилова ${ }^{\mathrm{a}}$, Е.И. Шишацкая ${ }^{\mathrm{a}, \overline{0}}$ \\ ${ }^{a}$ Сибирский федеральный университет \\ Россия, 660041, Красноярск, пр. Свободныий, 79 \\ ${ }^{6}$ Институт биофизики СО РАН \\ Федеральньй исследовательский иентр \\ «Красноярский научный центр СО РАН» \\ Россия, 660036, Красноярск, Академгородок, 50/50
}

Бактериальная иеелюолоза (БЦ) широко используется в медицине в качестве перевязочного материала благодаря своим биологическим свойствам - высокой бисовместимости, низкой адгезионности и способности поглощать раневой экссудат. Собственно БЦ не обладает антимикробной активностью, что ограничивает использование изделий при инфицированных ранах, а также при лечении ран в стационарах. Предложен вариант способа получения двухкомпонентного композитного материала на основе бактериальной целлюлозы (БЦ), синтезированной культурой Komagataeibacter xylinus B-12068, с наночастицами серебра [БЦ/AgNps] путем гидротермального синтеза $\mathrm{AgNO}_{3}$ в толще пласта при различных температурных режимах и концентрациях $\mathrm{AgNO}_{3}$. С использованием дискодиффузионного метода подтверждена антибактериальная активность образиов БЦ/AgNps в отношении Escherichia coli, Pseudomonas aeruginosa, Klebsiella pneumoniae u Staphylococcus aureus. Показано, что антибактериальная активность образиов композита наиболее выражена по отношению P. aeruginosa и S. aureus.

Ключевые слова: бактериальная иุеллюлоза, наночастииы серебра, композиты, бактерицидная активность.

\section{Introduction}

Bacterial cellulose $(\mathrm{BC})$ is a biopolymer, synthesized by microorganisms, similar in chemical structure to plant cellulose, but possessing unique physico-mechanical and chemical properties. $\mathrm{BC}$ is characterized by high biocompatibility, does not show cytotoxicity or allergic reactions. The $\mathrm{BC}$ demonstrates no adhesion towards opened soft tissues, so it can be an ideal material for the wound dressings and other medical devices, intended for the contact with inner medium of human body (Ul-Islam et al., 2013). Gel-films of BC have an ordered structure and represent a three-dimensional network structure, consisting of evenly distributed ribbon-like microfibrils. Complex of these properties in a combination with cheapness and simplicity of the synthesis make $\mathrm{BC}$ very popular for the investigations as a material for the restoration of skin, bones, connective tissues of different structure, blood vessels, the basis for drug deposition and delivery, etc. (Saska et al., 2011; Castro et al., 2012; Petersen, Gatenholm, 2011; Keshk, 2014).

Compositions of $\mathrm{BC}$ with various materials - chitosan (Lin et al., 2013), collagen (Wen et al., 2015), sodium alginate, gelatin, polyethylene glycol (Shah et al., 2013) are 
produced to improve the physico-mechanical properties and functionality of the resulting biomaterial. Bacterial cellulose itself does not possess antimicrobial activity. However, taking into account its favorable structure, it is possible to use it in a composition with "incrusting the surface" heavy metal nanoparticles, wherein they will act as a local agent for directed kill of bacteria, thereby possessing conditions for faster wound healing (Czaja et al., 2004; Yang et al., 2012).

Metallic silver and its forms and compounds have a pronounced bactericidal effect, inhibiting the development of a lot of pathogenic microorganisms. Silver ions interact with thiol groups of cell wall proteins, disrupting bacterial respiration and transporting substances through the cell membrane (Percival et al., 2005). Composite biomaterials "polymer/metallic nanoparticles" can be prepared in several ways: by mechanically mixing the polymer with metal nanoparticles in the form of powder or suspension, with the polymerization of the monomers in situ in the presence of metal nanoparticles, or by chemical reduction, for example sodium borohydride (Yang et al., 2012a; Wua et al., 2015). In the latter case, the plurality of hydroxyl groups on microfibrils of bacterial cellulose serve as anchor areas for silver ions, limiting the growth of the particles within the pores, realizing their controlled agglomeration and narrowing the size distribution as a result.

The purpose of this work is to obtain and to characterize bacterial cellulose composites with silver nanoparticles.

\section{Materials and methods}

Bacterial cellulose films were synthesized in culture Komagataeibacter xylinus B-12068 with the method of surface culturing in static conditions. To remove remnants of bacterial cells and components of grow medium BC films were treated with $1.0 \mathrm{M} \mathrm{NaOH}$ at $70{ }^{\circ} \mathrm{C}$, with following streamed washing in deionized water. For BC composites with silver nanoparticles a hydrothermal method was used, without the utilization of any catalysts, using the discs of $\mathrm{BC}$ layer as a reducing and stabilizing agent (Yang et al., 2012). Cleaned wet BC films were cut into discs with an average diameter of $10 \mathrm{~mm}$, then were placed in a flask with 0.001 $\mathrm{M} \mathrm{AgNO}$ solution and heated for 60 minutes to 30,60 and $90^{\circ} \mathrm{C}$. Also, the effect of different concentrations of $\mathrm{AgNO}_{3}$ in the reactionary medium was estimated for $0.0001,0.001$ and $0.01 \mathrm{M}$, with the selected temperature in the system $90{ }^{\circ} \mathrm{C}$.

Parameters of resulting silver nanoparticles were investigated with a Zetasizer Nano ZS particle analyzer (Malvern, U.K.), employing dual angle dynamic light scattering. Composite films of $\mathrm{BC}$ with silver nanoparticles $[\mathrm{BC} /$ AgNps] were lyophilized at $-40{ }^{\circ} \mathrm{C}$ and pressure of 0.12 mbar for one day in a unit ALPHA 1-2/LD ("MartinChristGmbH", Germany). The microstructure of samples was examined using scanning electron microscopy with TM-3000 microscope with Hitachi X-ray analysis system and QUANTAX 70 program.

Thermal analysis of samples was performed using an STA 449 Jupiter synchronous thermal analyzer (NETZSCH, Germany) for simultaneous thermogravimetry and differential scanning calorimetry (DSC), combined with a QMS 403 Aeolus quadrupole mass spectrometer for analysis of gases, and evolved by the heating specimens. $\mathrm{X}$-ray structure analysis and determination of crystallinity of films $\left(\mathrm{C}_{\mathrm{x}}\right)$ were performed using a D8 ADVANCE X-ray spectrometer ("Bruker", Germany), with graphite monochromator on a reflected beam.

To estimate the antimicrobial activity of $\mathrm{BC} /$ AgNps discs, they were preliminary autoclaved with $120{ }^{\circ} \mathrm{C}$ at $0.5 \mathrm{~atm}$. The direct inhibitory 
effect of BC/AgNps was tested on cultures of Escherichia coli, Pseudomonas aeruginosa, Klebsiella pneumoniae, and Staphylococcus aureus using disc diffusion method in agar on Petri dishes. The diameter of the growth inhibition zones and the distance from the edge of the film to the end of the zone were measured in photographs of dishes, using the Image J program. The results were processed using the Microsoft Excel application package. The arithmetic mean and standard deviation were calculated.

\section{Results and discussion}

Two modes of hydrothermal preparation of the bacterial cellulose composite with silver nanoparticles [BC/AgNps] were used: a change in the temperature and $\mathrm{AgNO}_{3}$ concentration in the reaction solution; this provided a series of samples (Fig. 1). The change in the temperature of the medium with the $\mathrm{AgNO}_{3}$ concentration of $0.001 \mathrm{M}$ had a different effect on the size of the silver nanoparticles formed. After incubation of $\mathrm{BC}$ films in a solution of silver nitrate at $30^{\circ} \mathrm{C}$, there appeared to be an aggregation of the silver particles formed and their average size was recorded at $757 \mathrm{~nm}$. When the temperature of the reaction solution was increased to 60 and $90{ }^{\circ} \mathrm{C}$, the particle size was significantly reduced, to 45 and $13 \mathrm{~nm}$, respectively. The use of $\mathrm{AgNO}_{3}$ solutions of different concentrations $(0.0001,0.001$ and $0.01 \mathrm{M})$ with stabilization of the medium temperature at $90{ }^{\circ} \mathrm{C}$ provided the
A
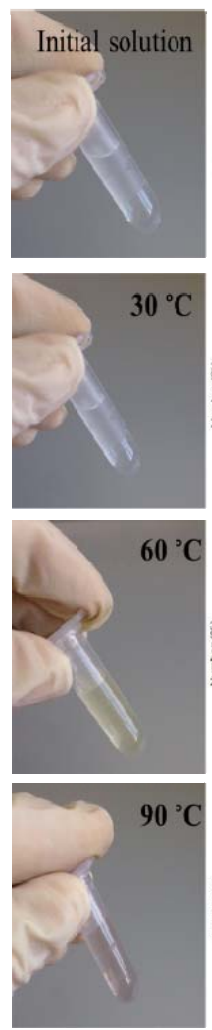

B

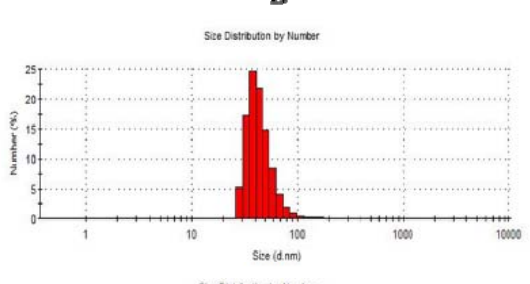

Ses Distrivofion by Hurter
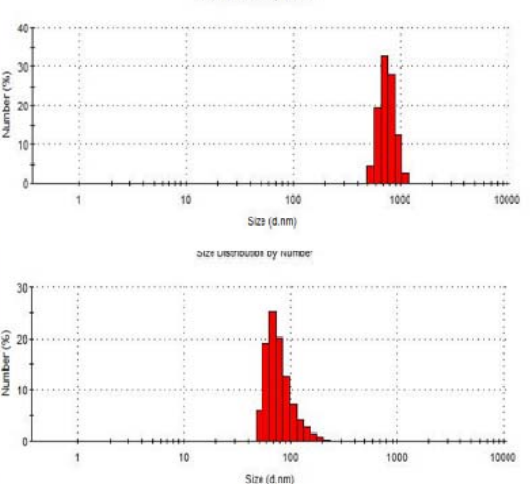

Size Disteutben ty Nurbes

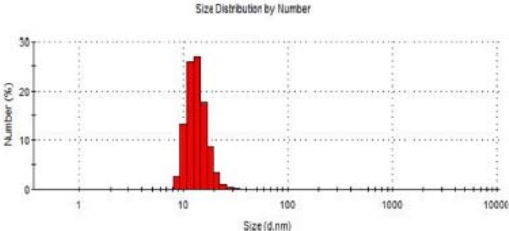

A
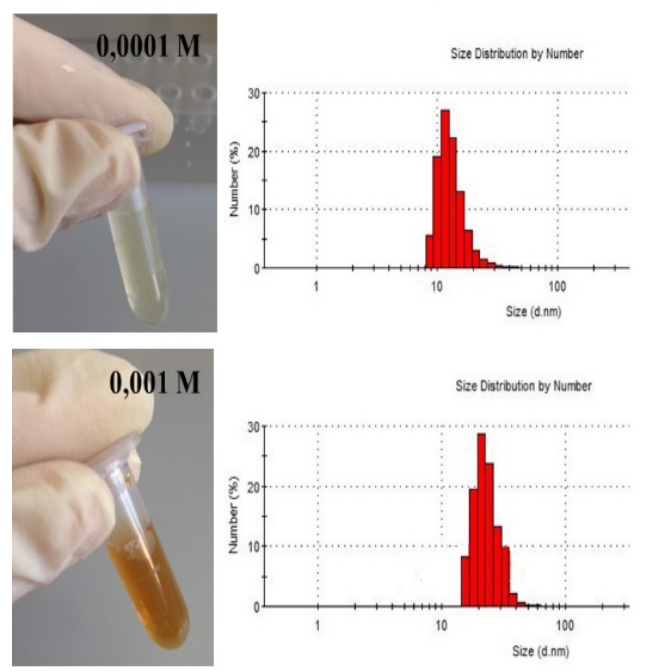

0,01 M

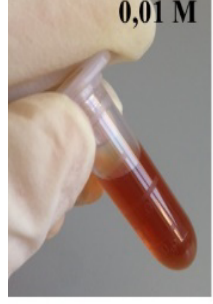

B

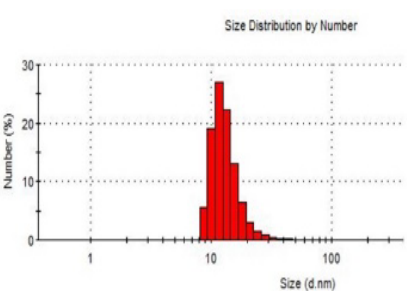

(d.nm)

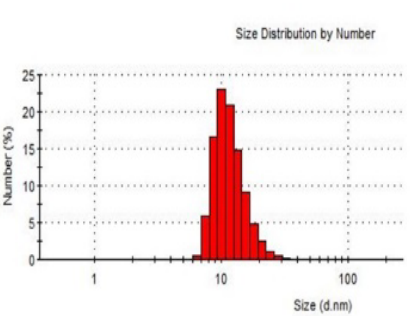

Fig. 1. An appearance of the reaction medium (A) and size distribution of Ag-nanoparticles in the system (B) during the synthesis of composite films in three regimes of temperature (left) and with varied concentrations of $\mathrm{AgNO}_{3}$ in the reaction solution (right) 
formation of silver nanoparticles with an average size of 13, 23 and $12 \mathrm{~nm}$, respectively.

A photo of bacterial cellulose composite films with silver nanoparticles is shown in Fig. 2. The presence of silver in the BC-films was confirmed with the scanning electron microscopy and X-ray spectra analysis (Table 1). It was shown, that the average mole percentages of silver in composite
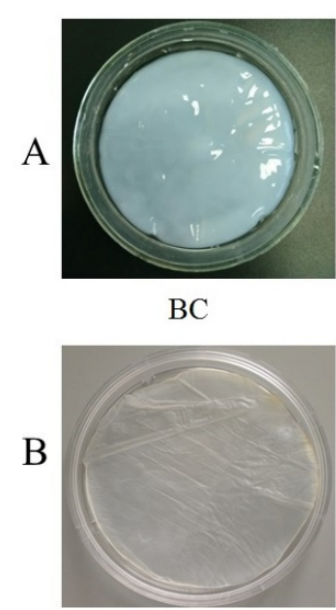

$\mathrm{BC}$

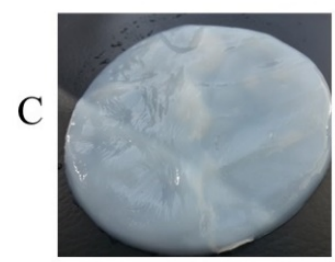

$\mathrm{BC}$

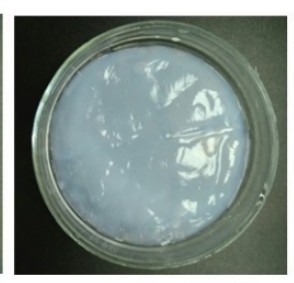

$\mathrm{BC} / \mathrm{AgNps} 30^{\circ} \mathrm{C}$

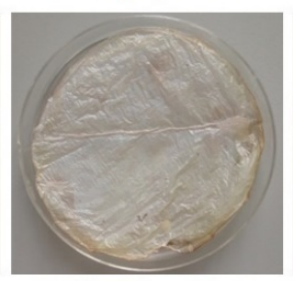

$\mathrm{BC} / \mathrm{AgNps} 30^{\circ} \mathrm{C}$

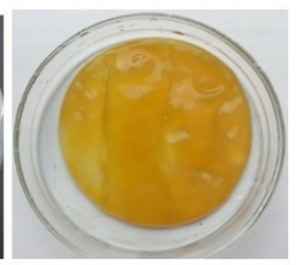

BC/AgNps 0,0001M

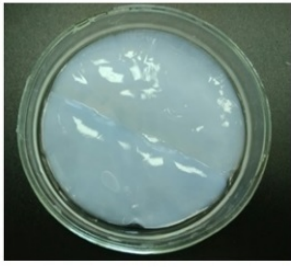

$\mathrm{BC} / \mathrm{AgNps} 60^{\circ} \mathrm{C}$

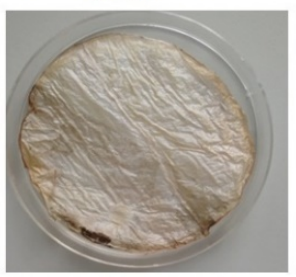

$\mathrm{BC} / \mathrm{AgNps} 60^{\circ} \mathrm{C}$

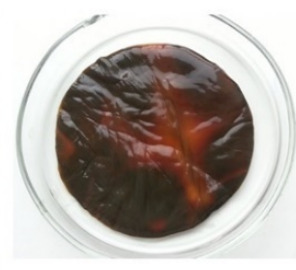

$\mathrm{BC} / \mathrm{AgNPs} 0,001 \mathrm{M}$

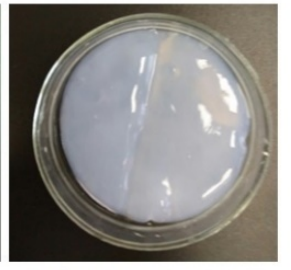

$\mathrm{BC} / \mathrm{AgNps} 90^{\circ} \mathrm{C}$

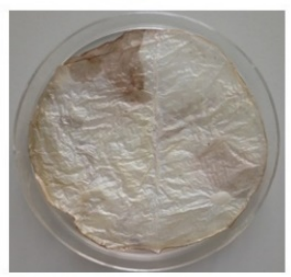

$\mathrm{BC} / \mathrm{AgNps} 90^{\circ} \mathrm{C}$

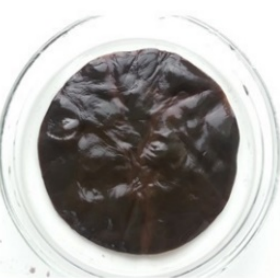

$\mathrm{BC} / \mathrm{AgNps} 0,01 \mathrm{M}$

Fig. 2. Photos of raw (A, C) and lyophilized (B) BC/AgNPs films synthesized in three regimes of temperature $(\mathrm{A}, \mathrm{B})$ and with varied concentrations of $\mathrm{AgNO}_{3}$ in the reaction solution (C)

Table 1. Influence of synthesis conditions on the element composition of composite BC films with silver nanoparticles

\begin{tabular}{|c|c|c|c|c|}
\hline \multirow{2}{*}{ Samples } & \multicolumn{4}{|c|}{ Average mole \% of the total elements } \\
\cline { 2 - 5 } & $\mathrm{O}$ & $\mathrm{C}$ & $\mathrm{N}$ & $\mathrm{Ag}$ \\
\hline BC film & 59.8 & 40.1 & - & - \\
& \multicolumn{4}{|c|}{ Influence of temperature at $0.001 \mathrm{M} \mathrm{AgNO}_{3}$} \\
$30^{\circ} \mathrm{C}$ & 52.9 & 42.5 & 1.1 & 3.0 \\
$60^{\circ} \mathrm{C}$ & 51.0 & 40.3 & 0.6 & 3.3 \\
$90^{\circ} \mathrm{C}$ & 52.3 & 41.7 & 1.5 & 3.7 \\
& \multicolumn{2}{c}{ Influence of $\mathrm{AgNO}_{3}$ concentration at $90^{\circ} \mathrm{C}$} \\
$0.0001 \mathrm{M}$ & 51.0 & 43.9 & 1.4 & 1.0 \\
$0.001 \mathrm{M}$ & 54.2 & 41.7 & 0.6 & 3.6 \\
$0.01 \mathrm{M}$ & 50.2 & 40.7 & 1.2 & 5.3 \\
\hline
\end{tabular}


samples depended on the temperature in system insignificantly, and was 3.08, 3.32 and 3.71 at 30 , 60 and $900 \mathrm{C}$, respectively. In contrast, increasing of concentration of $\mathrm{AgNO}_{3}$ in the reaction solution from 0.001 to $0.01 \mathrm{M}$ was accompanied by a increasing of silver content in the composites from 1.08 to $5.32 \%$.

To identify the appearance of possible structural changes in the composite, X-ray diffraction analysis and differential scanning calorimetry were involved. In BC samples without inclusion of $\mathrm{Ag}$ the degree of crystallinity was measured as 75 and $72 \%$. For samples, obtained at the highest concentration of $\mathrm{AgNO}_{3}$ in the system and the high content of silver in the composite $(5.3 \%)$ with an average size of nanoparticles $12 \mathrm{~nm}$, the degree of crystallinity decreased up to $61 \%$ (Fig. 3). With a decrease in the content of silver in the composite to $3.6 \%$ and $1 \%$, the degree of crystallinity increased to 83 and $86 \%$, respectively, that was higher than the value of pure $\mathrm{BC}$. It should be noted, that the
$\mathrm{C}_{\mathrm{x}}$ of $\mathrm{BC}$ is significantly influenced by the type and conditions of the biosynthesis and the carbon substrate, and, according to the literature data and our own results, may be from 45 to $90 \%$ (Shah et al., 2013; Shao et al., 2015).

The results of differential scanning calorimetry showed that the samples of pure cellulose did not have clearly defined peaks in the field of thermal degradation. Therefore, an important parameter for this natural polymer is the temperature of the onset of destructive processes $\left(\mathrm{T}_{\text {o. d. }}\right)$. Unlike $\mathrm{BC}, \mathrm{BC}$ composites with silver nanoparticles obtained at different regimes had some differences and were characterized by greater thermostability (Fig. 4).

Thus, composites obtained at different temperatures, but with a similar content of silver in BC films (approximately of $3 \%$ ), had, in comparison with the $\mathrm{BC}$, more pronounced peaks in the thermal degradation region $\left(415-425^{\circ} \mathrm{C}\right)$; the onset of the decomposition temperature for the samples was in the region of $320-325{ }^{\circ} \mathrm{C}$

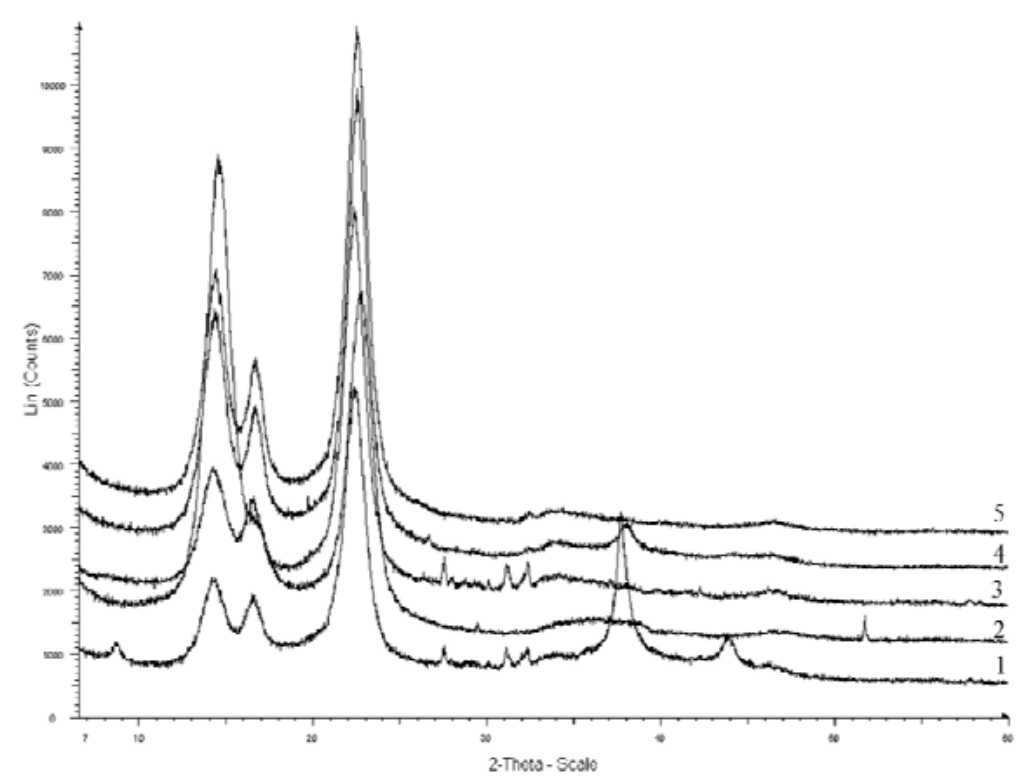

Fig. 3. X-ray patterns of the $\mathrm{BC}$ composite with silver nanoparticles obtained at different concentrations of $\mathrm{AgNO}_{3}$ in the reaction solution: $1-0.01 \mathrm{M}, 4-0.001 \mathrm{M}, 5-0.0001 \mathrm{M}$; the degree of crystallinity $\left(\mathrm{C}_{\mathrm{x}}\right) 61,83$ and $86 \%$, respectively; 2 and 3 - the starting cellulose (without silver), the degree of crystallinity 72 and $75 \%$ 

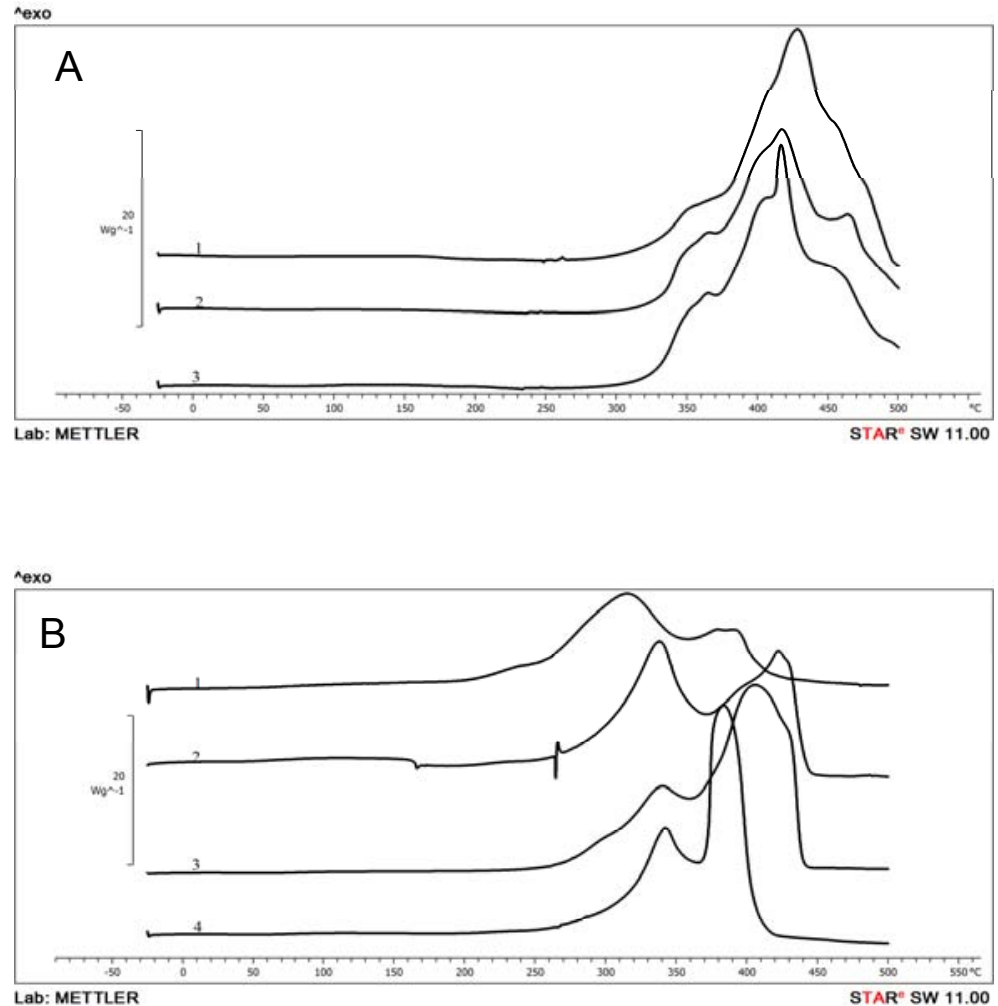

Fig. 4. DSC curves: $\mathrm{A}-1,2$ and 3 - the BC composite with silver nanoparticles obtained in a solution of $0.001 \mathrm{M}$ $\mathrm{AgNO}_{3}$ at 30,60 and $90{ }^{\circ} \mathrm{C}$, respectively; $\mathrm{B}-1$ - initial cellulose, freeze-dehydrated; 2,3 and 4 - the composite obtained at $90^{\circ} \mathrm{C}$ and different concentrations of $\operatorname{AgNO}_{3}(0.01 \mathrm{M}, 0.001 \mathrm{M}$, and $0001 \mathrm{M}$, respectively)

(Fig. 4A); this is significantly higher (almost 60$80{ }^{\circ} \mathrm{C}$ ) than in the $\mathrm{BC}$ samples. The composites obtained by stabilizing the temperature at the level of $90{ }^{\circ} \mathrm{C}$, but at different concentrations of $\mathrm{AgNO}_{3}$ in the reaction medium, also showed higher thermal stability than the BC (Fig. $4 B$, curve 1). In all composite samples, the regions of onset of thermal degradation were shifted to the right with regard to the $\mathrm{BC}$; at the same time they were characterized by the presence of two peaks with a gap between them from 40 to $120^{\circ} \mathrm{C}$ (Fig. $4 B$, curves 2-4). In general, the filling of cellulose films with silver nanoparticles increased the thermal stability of BC.

All samples of BC/AgNps composite, independently on the preparation conditions and content of silver nanoparticles, had a bactericidal effect, as shown in test cultures of pathogenic bacteria. Since inclusion of Ag-particles has a negative impact both, to the cell of tissues, in particular, actively dividing cells in wound regeneration zone, and to pathogenic bacteria, for the investigations of products, intended to the direct contact with wound medium, were taken samples with an average content of silver of medium value (about $3 \%$ ). Four strains were studied - three Gram-negative: Escherichia coli, Klebsiella pneumoniae, Pseudomonas aeruginosa, and one - Gram-positive - Staphylococcus aureus, as they are the main representatives of the pathogenic flora of infected wounds.

Antibacterial effect of $\mathrm{BC} / \mathrm{AgNps}$ composite in direct contact with the cultures was expressed in different degrees for the different strains. In general, E. coli and $K$. pneumoniae were less sensitive, $P$. aeruginosa and St. aureus more 
sensitive. Also, significant differences were found towards the samples obtained at 60 and $90{ }^{\circ} \mathrm{C}$ (Fig. 5, Table 2). The observed differences in diameters of growth suppression zones can be explained by the physiological characteristics of strains, that causes their different sensitivity to the direct contact with silver ions in BC/AgNps composites (Ruparelia, 2008).

It is known, that the cytotoxic activity of Ag-nanoparticles depends on their size and concentration, whereas the minimum inhibiting concentration of $\mathrm{Ag}$ nanoparticles is

A

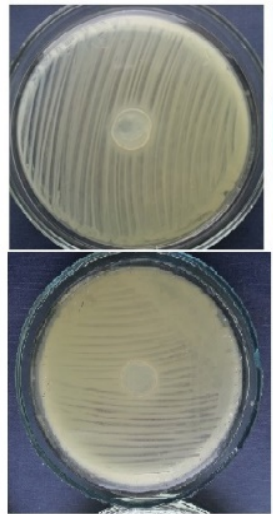

$\mathrm{C}$

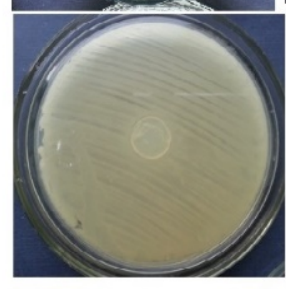

$\mathrm{D}$

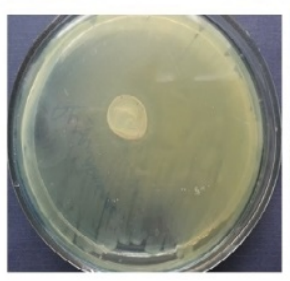

1
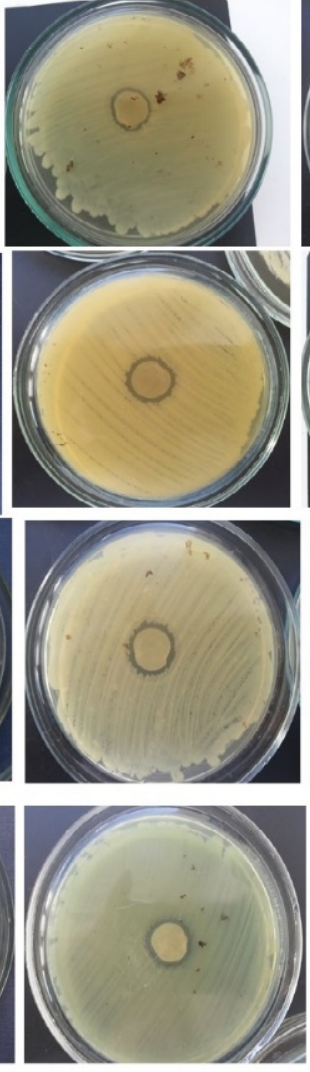

2
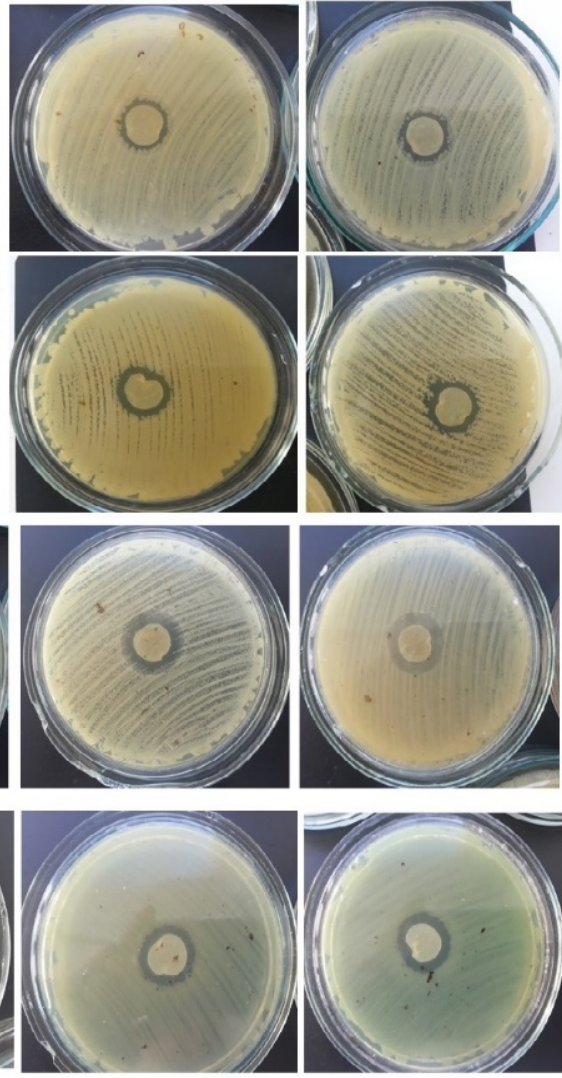

3

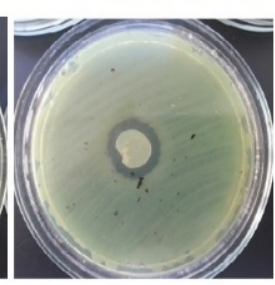

4

Fig. 5. The grow suppression zones in cultures Escherichia coli (A), Klebsiella pneumoniae (B), Pseudomonas aeruginosa (C), and Staphylococcus aureus (D), with the diffusion test with: 1 - pure BC-films, 2, 3, and 4 $\mathrm{BC} / \mathrm{AgNps}$, synthesized with different temperatures $\left(30^{\circ} \mathrm{C}, 60^{\circ} \mathrm{C}\right.$, and $\left.90{ }^{\circ} \mathrm{C}\right)$

Table 2. Diameter of the zones of bacterial growth inhibition by composite BC films with silver nanoparticles obtained under various temperature conditions of the reaction medium

\begin{tabular}{|c|c|c|c|}
\hline \multirow{2}{*}{ Bacterial test culture } & \multicolumn{3}{|c|}{ Diameter of inhibition zones (mm) } \\
\cline { 2 - 4 } & $30^{\circ} \mathrm{C}$ & $60^{\circ} \mathrm{C}$ & $90^{\circ} \mathrm{C}$ \\
\hline E. coli & $14 \pm 0.20$ & $16 \pm 0.50$ & $17 \pm 0.61$ \\
K. pneumoniae & $15 \pm 0.44$ & $16 \pm 0.64$ & $17 \pm 0.36$ \\
P. aeruginosa & $15 \pm 0.90$ & $18 \pm 1.15$ & $21 \pm 2.11$ \\
St. aureus & $15 \pm 0.73$ & $19 \pm 0.28$ & $20 \pm 1.58$ \\
\hline
\end{tabular}


0.05-0.1 mg/ml (Castro-Mayorga et al., 2014; Bindhu et al., 2015). We found, that with the concentration of the $\mathrm{AgNO}_{3}$ solution of $0.001 \mathrm{M}$, the level of incorporated silver in BC films varied slightly, in range of 3.1-3.7 \%. Composites obtained at higher temperatures showed a more pronounced inhibiting effect on bacteria. There is evident that the ambient temperature plays an important role in the antimicrobial activity of silver ions (Kulsky, 1980).

Thus, our results confirmed that the inhibition effect of $\mathrm{BC} / \mathrm{AgNps}$ composite against pathogenic bacteria through the direct contact action in vitro was more noticeable in cases when composite samples synthesized at temperatures 60 and $90{ }^{\circ} \mathrm{C}$ were used. This phenomenon can be explained both with dimensional characteristics of the Ag-particles in composite discs formed at these temperatures and with a straight line relationship between the antibacterial activity and the content of Ag particles per unit of the surface of the samples.

\section{Conclusion}

The different modes of synthesis of composite bacterial cellulose wound coverings with silver nanoparticles intended for wounds infected with Gram-negative and Gram-positive bacteria were investigated. An inclusion of silver nanoparticles into the structure of bacterial cellulose layer with hydrothermal synthesis at 60 and $90{ }^{\circ} \mathrm{C}$ provides the formation of bio-active surface of $\mathrm{BC} / \mathrm{AgNps}$ composite hydrogel films having antibacterial influence to the wound pathogenic flora, which is more noticeable for $E$. coli and $K$. pneumoniae.

\section{Acknowledgments}

The reported study was funded by RFBR and Government of Krasnoyarsk Territory according to the research project № 16-43-242024, and by the State budget allocated to the fundamental research at the Russian Academy of Sciences (№ AAAA-A17-117013050028-8) - electron microscopy of samples.

\section{References}

Bindhu M.R., Umadevi M. (2015) Antibacterial and catalytic activities of green synthesized silver nanoparticles. Spectrochimica Acta Part A: Molecular and Biomolecular Spectroscopy, 135: 373-378

Castro C., Zuluaga R., Alvares C., Putaux J-L., Caro G., Rojas O., Mondragon I., Ganan P. (2012) Bacterial cellulose produced by a new acid-resistant strain of Gluconacetobacter genus. Carbohydrate Polymers, 89 (4): 1033-1037

Castro-Mayorga J.L., Martínez-Abad A., Fabra M.J., Olivera C., Reis M., Lagarón J.M. (2014) Stabilization of antimicrobial silver nanoparticles by a polyhydroxyalkanoate, obtained from mixed bacterial culture. International Journal of Biological Macromolecules, 7: 103-110

Czaja W., Romanovicz D., Brown R.M.Jr. (2004) Structural investigations of microbial cellulose produced in stationary and agitated culture. Cellulose, 11: 403-411

Keshk S.M. (2014) Bacterial cellulose production and its industrial applications. Journal of Bioprocessing \& Biotechniques, 4(2): 1-10

Kulsky L.A. (1980) Theoretical foundations and technology of water conditioning. Kiev, Naukova Dumka, 564 p. (in Russian)

Lin W.C., Lien C., Yeh H.J., Yu C.M., Hsu S.H. (2013) Bacterial cellulose and bacterial cellulosechitosan membranes for wound dressing applications. Carbohydrate Polymers, 94(1): 603-611

Percival S.L., Bowler P.G., Russell D. (2005) Bacterial resistance to silver in wound care. Journal of Hospital Infection, 60: 1-7

$$
-263-
$$


Petersen N., Gatenholm P. (2011) Bacterial cellulose-based materials and medical devices: current state and perspectives. Applied Microbiology and Biotechnology, 91(5): 1277-1286

Ruparelia J.P., Chatterjee A.K., Duttagupta S.P., Mukherji S. (2008) Strain specificity in antimicrobial activity of silver and copper nanoparticles. Acta Biomaterialia, 4(3): 707-716

Saska S., Barud H.S., Gaspar A.M.M., Marchetto R.,. Ribeiro S.J.L., Messaddeq Y. (2011) Bacterial cellulose-hydroxyapatite nanocomposites for bone regeneration. International Journal of Biomaterials, 2011: 1-8

Shah N., Ul-Islam M., Khattak W.A., Park J.K. (2013) Overview of bacterial cellulose composites: a multipurpose advanced material. Carbohydrate Polymers, 98(2): 1585-1598

Shao W., Liu H., Liu X., Sun H., Wang S., Zhang R. (2015) pH-responsive release behavior and anti-bacterial activity of bacterial cellulose-silver nanocomposites. International Journal of Biological Macromolecules, 76: 209-217

Ul-Islam M., Ha J.H., Khan T., Park J.K. (2013) Effects of glucuronic acid oligomers on the production, structure and properties of bacterial cellulose. Carbohydrate Polymers, 92(1): 360-366

Wen X., Zheng Y., Wu J., Wang L.N., Yuan Z., Peng J., Meng H. (2015) Immobilization of collagen peptide on dialdehyde bacterial cellulose nanofibers via covalent bonds for tissue engineering and regeneration. International Journal of Nanomedicine, 10: 4623-4637

Wua J., Zhenga Y., Song W., Luana J., Wena X., Wuc Z., Chend X., Wanga Q., Guoa S. (2015) In situ synthesis of silver-nanoparticles/bacterial cellulose composites for slow-released antimicrobial wound dressing. Carbohydrate Polymers, 102: 762-771

Yang G., Xie J., Deng Y., Bian Y., Hong F. (2012) Hydrothermal synthesis of bacterial cellulose/ AgNPs composite: a "green" route for antibacterial application. Carbohydrate Polymers, 87(4): 2482-2487

Yang G., Xie J.J., Hong F., Cao Z.J., Yang X.X. (2012a) Antimicrobial activity of silver nanoparticle impregnated bacterial cellulose membrane: Effect of fermentation carbon sources of bacterial cellulose. Carbohydrate Polymers, 87: 839-845 